\title{
EL OCIO COTIDIANO DE LOS ESTUDIANTES \\ DE EDUCACIÓN SECUNDARIA EN ESPAÑA'
}

\author{
LEISURE TIME IN HIGH SCHOOLS' \\ STUDENTS IN SPAIN²
}

\section{O LAZER NO QUOTIDIANO DOS ESTUDANTES DE EDUCAÇÃO SECUNDÁRIA EM ESPANHA}

\author{
Joao Paulo Ferreira Delgado \\ Escola Superior de Educação do Instituto Politécnico do Porto, Portugal \\ Héctor Pose Porto \\ Universidade dA Coruña, España
}

Ángela Lucía De Valenzuela Bandín

Universidad de Santiago de Compostela, España

RESUMEN: Partiendo de la interrelación existente entre la educación cultural de las personas y el uso que hacen de sus tiempos cotidianos, en el artículo se pone de manifiesto la relevancia que tiene el ocio en el desarrollo humano. Más aún cuando nos referimos a adolescentes y jóvenes que, dada la realidad socio familiar que les ha venido impuesta, ven condicionada la satisfacción de muchas de las necesidades básicas que favorecen una vida de y con calidad, en cuyo logro el derecho al ocio adquiere un protagonismo clave.

En este sentido, se presentarán parte de los resultados de un proyecto de investigación, cuyo objetivo principal residía en conocer e interpretar cómo inciden los tiempos escolares en los procesos de socialización adolescente y juvenil, así como en los modos de configurar su tiempo libre.

Más en concreto: se analizarán algunos de los datos obtenidos en un cuestionario diseñado ad hoc y aplicado a una muestra de 3.306 alumnos/as de entre 12 y 17 años que cursaban Educación Secundaria Obligatoria (ESO) en centros educativos de la geografía española en el curso académico 2010-2011. Conocer la utilización que hace este colectivo de sus tiempos, tiene para nosotros en este artículo una doble finalidad: reflexionar en qué medida las actividades que realizan favorecen la adquisición de aprendizajes de carácter cultural; indagar si existe alguna relación significativa entre la edad, el contexto familiar y las actividades que llevan a cabo.

PALABRAS CLAVE: Pedagogía social; adolescencia; tiempos sociales; ocio cotidiano; educación del ocio.

ABSTRACT: Considering the interrelation between people's cultural education and how they use their daily time, this article highlights the relevance of leisure time in human development. Especially when we 
refer to the group of young people who, given the social and familial reality that has been imposed to them, feels limitations in what concerns the satisfaction of their basic needs, among them enjoying a leisure time that favors their quality of life.

In this sense, we present some results of a research project carried out on Spanish territory and whose main objective was to learn and interpret how time in school is reflected in students' socialization process, as well as how they configure leisure time.

The data were obtained by a questionnaire designed ad hoc that was applied to a sample of 3.306 youth, from 12 to 17 years, who attended Secundary Education (ESO) 3 in Spanish High Schools in the academic year of 2010-2011. Our intention is to know how students spend their time, with two purposes: reflecting about the extent to which their activities favor the acquisition of cultural learning cultural, and whether there is any significant relationship between age and type of recreational activities they undertake.

KEYWORDS: Social pedagogy; adolescence; social time; leisure time; leisure education.

RESUMO: Partindo da inter-relação entre a educação cultural das pessoas e o uso que fazem dos seus tempos quotidianos, este artigo evidencia a relevância que têm os tempos de lazer no desenvolvimento humano. Especialmente quando nos referimos ao grupo de adolescentes e jovens que, dada a realidade sociofamiliar que lhes tem sido imposta, vê condicionada a satisfação de muitas das necessidades básicas que possibilitam uma vida de e com qualidade, na qual o direito ao lazer adquire um protagonismo chave.

Neste sentido, serão apresentados parte dos resultados de um projeto de investigação cujo objetivo principal era conhecer e interpretar os modos como configuram os seus tempos livres e como os tempos escolares se refletem nos processos de socialização adolescente e juvenil.

Concretamente, serão analisados alguns dos dados obtidos pelo questionário desenhado ad hoc e aplicado a uma amostra de 3.306 jovens com 12 e 17 anos que frequentavam a Educación Secundaria Obligatoria (ESO) nos centros educativos do território espanhol no curso académico de 2010-2011. Conhecer a utilização que os adolescentes e jovens fazem dos seus tempos tem uma dupla finalidade: refletir em que medida as atividades que realizam favorecem a aquisição de aprendizagens de caráter cultural; questionar se existe alguma relação significativa entre a idade e as atividades que realizam.

PALAVRAS-CHAVE: Pedagogia social; adolescência; tempos sociais; lazer no quotidiano; educação para o lazer.

\section{Introducción}

A menudo, con un afán de superación y competitividad, focalizamos el desarrollo y la educación de las personas sólo en el ámbito familiar, los aprendizajes académicos y el trabajo remunerado, obviando la existencia de otros tiempos y espacios educativos -y educables- que contribuyen decisivamente a la formación integral de los sujetos, ampliando significativamente sus expectativas de bienestar.

En este sentido, el tiempo de ocio -y su educación- en tanto que experiencia humana autotélica, liberada de coacciones, adquiere un especial interés. De ahí, que coincidamos con Cuenca (2009a: 21) en que no se puede considerar como un tiempo so-

\section{Introduction}

Often, with a desire of improvement and competitiveness, we just focus people's development and education in family, academic learning and paid work, ignoring the existence of other situations and areas (educational and educable) that decisively contribute to individual training, significantly enhancing their well-being expectations.

In this sense, leisure time - and education - as an autotelic human experience, freed from coercion, acquires a special interest. Hence, we shared the view of Cuenca (2009a: 21) that it can not be seen as spare time, after doing other activities,

[ 26 ] JOAO PAULO FERREIRA DELGADO, HÉCTOR POSE PORTO Y ÁNGELA LUCÍA DE VALENZUELA BANDíN SIPS - PEDAGOGIA SOCIAL. REVISTA INTERUNIVERSITARIA [1139-1723 (2015) 25, 25-49] TERCERA ÉPOCA 
brante, después de realizar otras actividades, ya que "hábitos y prácticas de ocio tienen una incidencia importante en nuestra vida y contexto vital".

A pesar de que el término 'ocio' no aparece recogido de forma explícita en la Declaración Universal de los Derechos Humanos (1948), en su articulado se hace referencia al derecho a un tiempo de descanso, de disfrute y de participación en la comunidad: "toda persona tiene derecho al descanso, al disfrute del tiempo libre, a una utilización razonable de la duración del trabajo y a vacaciones periódicas pagadas" (art. 24), así como "a tomar parte libremente en la vida cultural de la comunidad y a gozar de las artes" (art. 27.1).

Stebbins (2012) expone en relación al colectivo de la juventud, y aquellos jóvenes que llevan a cabo prácticas delictivas, la necesidad de conocer con mayor profundidad el manejo que hacen de sus tiempos de ocio, teniendo en cuenta, no solo el tipo de actividades que realizan sino también la jornada escolar, la participación familiar y sus amistades. De este modo se evita la tendencia a limitar la cultura de ocio adolescente y juvenil al 'ocio ocasional', que a pesar de ser gratificante, libre y satisfactorio, implica un escaso desarrollo personal. En contraposición al denominado 'ocio serio' que conlleva sistematicidad, esmero, compromiso y oportunidades que afronten la exclusión social mediante la participación comunitaria.

La Pedagogía del Ocio entendida como el "arte de educar en y para la vivencia de un ocio humano y de calidad" (Cuenca, 2004: 94), implica la adquisición de conocimientos, actitudes, capacidades y valores en relación a las experiencias de ocio, favoreciendo un mejor desarrollo individual y social.

\section{Adolescencias e inclusión social: desafíos para el ocio y la educación cultural}

En los últimos años, los recortes inducidos por las políticas neoliberales han abocado a un creciente número de familias y, particularmente a muchos menores, a circunstancias de privación material, e incluso a la minoración o supresión de sus derechos humanos básicos, que comprometen su bienestar y expectativas futuras para una mayor calidad de vida.

Hechos que nos alejan de valores que identificaron históricamente los países política y social- since "habits and leisure practices have a major impact on our life and vital context".

Even if the term 'leisure' does not literally appear in the Universal Declaration of Human Rights (1948), there are some references in its articles to the right of having time for resting, enjoyment and community participation: "everyone has the right to rest and leisure, including reasonable limitation of working hours and periodic holidays with pay" (art. 24) as well as "freely to participate in the cultural life of the community, to enjoy the arts" (art. 27.1).

Regarding the youth collective, and those young who carry out criminal practices, Stebbins (2012) sets out the necessity to have a better knowledge of how they employ their leisure time, taking into account, not only the type of activities performed but also the school time, family engagement and their friendships. This prevents the tendency to limit the teenage and youth leisure culture to' an occasional leisure', which despite of being free, rewarding and satisfying, implies low personal development. Facing the so-called 'responsible leisure' which involves systematization, dedication, commitment and opportunities that face social exclusion through community participation.

The Leisure Pedagogy understood as the "art of education in and for the experience of leisure human and of quality" (Cuenca, 2004: 94), involves the acquisition of knowledge, attitudes, skills and values related to leisure experiences, promoting a better individual and social development.

\section{Teenagers and social inclusion: challenges for leisure and cultural education}

In recent years, the reductions induced by neo-liberal policies have dragged an increasing number of families and, particularly minors, towards circumstances of material deprivation, and even to a reduction or elimination of their basic human rights (involving their well-being and future expectations for a better quality of life).

Those facts take us away from values that were traditionally identified, politically and socially, with 
mente más avanzados en la lucha contra la pobreza, la distribución equitativa de los ingresos, la preocupación por la justicia social, el ejercicio activo de la democracia, o la ampliación de las oportunidades educativas y sociales.

Estar en situación de exclusión es, de acuerdo con Capucha et al. (2005), ser pobre y estar alejado del consumo de bienes y servicios básicos. En el caso de la infancia y de la adolescencia, la exclusión es también vivir el fracaso escolar y no participar en la sociedad del conocimiento y la información, carecer de una vivienda adecuada, no tener acceso a los servicios sociales o vivir en un territorio marginal.

La difícil y precaria inserción laboral de los jóvenes retrasa el proceso de autonomía y consolida la "concepción de la juventud como tiempo de espera, al dilatar cada vez más la asunción de las responsabilidades propias de la vida adulta" (Melendro, Rodríguez, González y De Juanas, 2013: 137). De ahí que alrededor de un tercio de los jóvenes españoles se encuentre actualmente en riesgo de pobreza y exclusión social.

El aumento de la pobreza infantil compromete los derechos humanos básicos, previstos en la Convención sobre los Derechos del Niño (1989). El hambre y la escasez de alimentos amenazan el derecho al desarrollo. La carencia de un espacio adecuado para estudiar, la falta de acceso a libros y la imposibilidad de participar en actividades escolares, compromete su artículo 28, en el que se consagra el derecho a la educación. Faltar a sus citas médicas o no tomar los medicamentos prescritos socava el derecho a la salud y a una atención médica adecuada (art. 24). La imposibilidad de practicar actividades extraescolares, no poder invitar a amigos/as a jugar o celebrar días especiales, viola el artículo 31 del citado texto, que establece el derecho al descanso y a los tiempos libres, el acceso a la cultura, las actividades recreativas y las artes. Las oportunidades y experiencias de ocio son estrategias preventivas contra el aislamiento y la exclusión, ya que contribuyen a la construcción de vínculos de identificación social, basados en la responsabilidad y la solidaridad (Delgado, 2006).

La Pedagogía-Educación del ocio, como ámbito de intervención de la Educación Social (Caride, 2005), se sitúa en la tensión que se da entre la pa- the more advanced countries in the fight against poverty, equitable distribution of income, the concern for social justice, the exercise of active democracy, or the expansion of educational and social opportunities.

Being in a situation of exclusion is, according to Capucha et al. (2005), being poor and being away from the consumption of basic goods and services. In the case of childhood and adolescence, the exclusion is also to live the school failure and not to participate in the society of knowledge and information, lack of an adequate housing, a lack of access to social services, or live in a marginal territory.

The difficult and precarious employment situation of youth slows down the autonomy process and strengthens the "conception of the youth as a time-out, postponing more and more the assumption of the responsibilities of adult life" (Melendro, Rodríguez, González and De Juanas, 2013:) 137). That is why about one third of young Spaniards is currently at risk of poverty and social exclusion.

The increase of child poverty endangers the basic human rights provided in the Convention on the Rights of the Child (1989). Hunger and food shortages threaten the right to development. The lack of an accurate place to study, the lack of access to books and the inability to participate in school activities, endanger its article 28, which enshrines the right to education. Missing medical appointments or not taking prescribed medicines undermines the right to health and to adequate health care (art. 24). The impossibility of participating in extracurricular activities, not to be able to invite friends over to play or celebrate special days, violates article 31 of the aforementioned text, which establishes the right to rest and to free time, access to culture, recreation and the arts. Opportunities and leisure experiences are preventive strategies against isolation and exclusion, since they contribute to the building of social identification bonds, based on responsibility and solidarity (Delgado, 2006).

The leisure Pedagogy-Education, as a field for Social Education intervention (Caride, 2005), is located in the tension that occurs between passivity and resignation in the time distribution, with 
sividad y la resignación en la ocupación del tiempo, con su uso volátil y frenético, y la vivencia del ocio como experiencia existencial. La modificación de los hábitos y estilos de ocio "constituyó un desafío para los procesos socioeducativos, para encontrar los modelos que promueven el mejor uso de los recursos y una experiencia útil de los tiempos libres, promoviendo el desarrollo personal y de transformación social" (Ferreira, Delgado \& Freitas, 2012: 162). De hecho, cabe entender la intervención socioeducativa como un proceso de mediación que propone el uso del tiempo libre en actividades formativas y enriquecedoras (Cuenca, 2011a).

Los tiempos libres caracterizados por la oportunidad de aprender y/o vivir momentos relevantes colectivamente, son ámbitos cotidianos $y$, en ocasiones, extraordinarios, para la inclusión de la infancia y particularmente de la que tiene que superar algunos obstáculos como los maltratos y las fases negativas en el desarrollo (Cyrulnik, 2002). Constituyen un tiempo importante para la integración en su contexto de vida y en la comunidad que les rodea, teniendo una valiosa función preventiva y de construcción de la resiliencia, entendida como la capacidad de hacer frente a las adversidades saliendo fortalecidos/as de las mismas (Jackson \& Sachdev, 2001; Gilligan, 2009).

\section{Metodología: diseño y desarrollo empírico}

El trabajo empírico realizado (entre los cursos académicos 2008-09 y 2010-11) ha tenido como soporte un diseño metodológico plural, basado en la combinación y triangulación de diferentes procedimientos (cualitativos-cuantitativos), técnicas (cuestionarios, grupos de discusión, estudio de casos, agendas y dietarios) y fuentes de información (documentos oficiales, personas e instituciones).

En este sentido, se han integrado cuestionarios elaborados ad hoc aplicados a distintas personas relacionadas con el tema-problema: el alumnado, las familias, el profesorado y el equipo directivo de los centros educativos. Todas ellas vinculadas con centros que imparten la ESO en las diecisiete Comunidades Autónomas del territorio español.

Para la selección de los sujetos se recurrió a un muestreo aleatorio estratificado basado en los si- its volatile and frenetic use, and to experience leisure as an existential experience. The modification of habits and forms of leisure "constituted a challenge to socio-educational processes, to find the models that promote the best use of resources and an useful experience of the free time, promoting personal development and social transformation" (Ferreira, Delgado \& Freitas, 2012:162). Indeed, socio-educational intervention can be understood as a mediation process which proposes the use of time in training and enriching activities (Cuenca, 2011a).

Free times characterized by the opportunity to learn and/or experience relevant moments collectively, are everyday areas, and, at times, extraordinary, for the inclusion of childhood and particularly of those that must overcome some obstacles such as abuse and negative phases in growth (Cyrulnik, 2002). Those constitute an important time for the integration in the context of life and in their community, having a valuable preventive and resilience-building role, understood as the capacity to cope with adversity coming out stronger (Jackson \& Sachdev, 2001; Gilligan, 2009).

\section{Methodology: design and empirical development}

The empirical work done (between the academic years 2008-09 and 2010-11) has been supported by a plural methodological design, based on the combination and triangulation of different procedures (qualitative-quantitative), techniques (questionnaires, groups of discussion, study cases and agendas) and sources of information (official documents, people and institutions).

In this regard, there have been added ad hoc questionnaires applied to people related to the issue-problem: students, families, staff and the management team of schools. All linked with institutions that GCSE in the seventeen autonomous communities of the Spanish territory.

In order to select the subjects, a stratified random sampling based on the following criteria was applied: representativeness at Spanish level, with 
guientes criterios: representatividad a nivel español, con sub muestras por cada Comunidad Autónoma, escolarización en centros públicos-privados y hábitat rural-urbano. La muestra se concretó en un $\mathrm{N}$ de 3.306 adolescentes, entre 12 y 17 años, estudiantes de la ESO en el curso 2010-11. Se trata de una participación elevada para la población de referencia, ya que -según el Ministerio de Educación, Cultura y Deporte (2012)- durante ese período el alumnado matriculado en esta etapa educativa fue de 1.786.754. La muestra es representativa, con un error muestral reducido $(e= \pm 2,3 \%)$ y un nivel de confianza elevado (99\%). Además, la distribución de la muestra (ver tabla 1) es equitativa en función del género (50,5\% chicas y $49,5 \%$ chicos). sub samples on each autonomous community, schooling in private or public centres and ruralurban habitat. Sample materialized in an $\mathrm{N}$ of 3.306 adolescents between 12 and 17 years, students of GCSE in the course 2010-11. It presents a high number for the reference population, since -according to the Ministry of Education, Culture and Sport (2012) - during this period the students enrolled in this educational stage was of 1.786 .754 . The sample is representative, with a reduced sampling error $(e= \pm 2.3 \%)$ and a high confidence level (99\%). In addition, the distribution of the sample (see table 1$)$ is equitable in gender $(50,5 \%$ girls and $49.5 \%$ boys).

Tabla 1. Datos de identificación de la muestra (\%). ( $\mathrm{N=3306,2010-2011)}$

\begin{tabular}{llllllllll}
\hline \multicolumn{2}{c}{ Sexo } & \multicolumn{2}{c}{ Edad (años) } & \multicolumn{2}{c}{$\begin{array}{c}\text { Nivel estudios } \\
\text { progenitores }\end{array}$} & \multicolumn{2}{c}{$\begin{array}{c}\text { Situación laboral } \\
\text { progenitores }\end{array}$} & & \multicolumn{2}{c}{ Tipología de familia } \\
\hline Chica & 50,5 & $12-13$ años & 41,2 & Bajo & 17,3 & Ninguno trabaja & 2,4 & Nuclear & 87,5 \\
\hline Chico & 49,5 & $14-15$ o más & 58,8 & Medio & 41,9 & Uno trabaja & 29,9 & Monoparental & 12,5 \\
\hline & & & Alto & 40,8 & Ambos trabajan & 67,7 & & \\
\hline
\end{tabular}

Fuente: Proyecto TETOSO (código PSI2008-04308/PSIC). Elaboración propia.

Table 1. Identification data of the sample (\%). (N=3306, 2010-2011)

\begin{tabular}{llllllllll}
\hline \multicolumn{2}{c}{ Gender } & \multicolumn{2}{c}{ Age (Years) } & \multicolumn{2}{c}{$\begin{array}{c}\text { Educational } \\
\text { level of parents }\end{array}$} & \multicolumn{2}{c}{$\begin{array}{c}\text { Employment situation of } \\
\text { parents }\end{array}$} & & Type of family \\
\hline Girl & 50,5 & $12-13$ years & 41,2 & Low & 17,3 & None of them work & 2,4 & Nuclear & \\
\hline Boy & 49,5 & $14-15$ or more & 58,8 & Medium & 41,9 & One works & 29,9 & Single-parent & 12,5 \\
\hline
\end{tabular}

Source: Proyecto TETOSO (code PSI2008-04308/PSIC). Personal compilation.

Se construyó una variable con tres categorías del nivel de estudios de los padres de los adolescentes. La categoría "bajo" incluye a familias en las que el padre y la madre carecen de estudios o poseen únicamente estudios primarios. El nivel "medio" está formado por aquellos casos en los que ambos progenitores poseen estudios secundarios, o se combinan estos con los primarios o los universitarios con una persona sin estudios. En la categoría "alto" se encuentran aquellas familias en las que un progenitor tiene estudios universitarios y el otro, al menos, secundarios.

La situación laboral se diferenció con los siguientes ítems: ninguno trabaja, uno de ellos trabaja y ambos lo hacen. En un 70\%, de las familias de los adolescentes encuestados, ambos progenitores tie-
A variable with three categories of the level of education of teenagers' parents was built. The category "low" includes families in which the father and the mother have no studies or have only primary education. The level "medium" consists on cases in which both parents have high school studies, or a combination of those with primary or university studies an person without studies. The category "high" is composed by those families in which one parent has university studies and the other, at least, secondary.

The employment situation was divided as: none of them works, one them works, and both do it. In a $70 \%$ of the surveyed teens families, both parents have remunerated employment, surely nowadays

[ 30 ] JOAO PAULO FERREIRA DELGADO, HÉCTOR POSE PORTO Y ÁNGELA LUCÍA DE VALENZUELA BANDÍN SIPS - PEDAGOGIA SOCIAL. REVISTA INTERUNIVERSITARIA [1139-1723 (2015) 25, 25-49] TERCERA ÉPOCA 
nen un empleo retribuido, seguramente hoy en día este porcentaje se ha reducido significativamente como consecuencia de la crisis económica.

En lo que se refiere a la estructura de las familias participantes, se crearon dos categorías: "nuclear", con dos adultos (progenitores) con uno o más hijos a su cargo, conviviendo o no con otros familiares; $y$ "monoparental", formada por un adulto (progenitor) con uno o más hijos a su cargo, conviviendo o no con otro familiar. En nuestra investigación, predomina claramente la tipología familiar nuclear (87,5\%).

Del conjunto de técnicas empleadas y fuentes consultadas, pondremos énfasis en los datos, de carácter cuantitativo, obtenidos mediante la aplicación del cuestionario al alumnado. Para su análisis se hizo uso del Statistical Package for the Social Sciences (SPSS), en la versión SPSS for Windows 16, del año 2007.

El diseño del cuestionario estaba destinado a captar las percepciones y los hábitos relacionados con la distribución y el uso del tiempo en adolescentes que cursaban la ESO. Con las informaciones obtenidas nos detendremos específicamente en el análisis tres variables: la edad (de 12 a 17 años), las actividades lúdicas que realizan los adolescentes durante los días lectivos o en fin de semana y el tiempo que le dedican.

En este primer nivel, se realiza un análisis descriptivo de las variables dependientes. Debido al carácter ordinal de éstas, para el estudio de la interacción entre variables se recurre a pruebas estadísticas no paramétricas, para indagar en qué medida el tiempo dedicado a las actividades de ocio se ve afectado por el nivel de estudios y la situación profesional de los padres (prueba de Kruskal-Wallis) y también por la tipología familiar (prueba de Mann-Whitney). A lo que se añade el propósito de analizar si existen relaciones significativas entre la edad y el tipo de actividades que realizan en su tiempo de ocio durante la semana lectiva y fin de semana los adolescentes, así como entre éstos y ciertas características estructurales o circunstanciales de sus progenitores.

\section{Análisis e interpretación de los resultados}

Centramos la atención en cuestiones que informan sobre las actividades que ocupan el tiempo libre de estos adolescentes y jóvenes, que transcurre cada this percentage is significantly lower as a result of the economic crisis.

Regarding the structure of the participating families, two categories were created: "nuclear", with two adults (parents) with one or more dependent children, living or not with other relatives; and "single-parent family", formed by an adult (parent) with one or more dependent children, living or not with another relative. In our research, the nuclear family typology predominates (87.5\%).

From the group of techniques and sources consulted, we will emphasize on those of quantitative data, obtained by applying the questionnaire to students. The analysis was done using the Statistical Package for the Social Sciences (SPSS), in its Windows 16 version, of the year 2007.

The design of the questionnaire was done to capture the perceptions and habits related to the distribution and the use of time in teenagers who were enrolled in the GCSE. Given the obtained information we will stop specifically at three variables' analysis: age (from 12 to 17), leisure activities that adolescents performed during the school days or week-end and the time they devote.

In this first level, a descriptive analysis of the dependent variables is performed. Due to their ordinal nature, non-parametric statistical tests are employed for the study of the interaction between variables, in order to investigate to what extent time spent on leisure activities is affected by the level of studies and the professional situation of the parents (Kruskal-Wallis Test) and also by family type (Mann-Whitney Test). It is also added the intention to analyse if there are significant relationships between age and the type of activities carried out by teenagers in their leisure time during the scholar week and weekend, as well as between them and certain circumstantial or structural characteristics of their parents.

\section{Analysis and results interpretation}

We focus our attention on issues that inform about activities that occupy these adolescents and young people-free time, which takes place each 
semana de lunes a viernes. Primeramente, valorando el tiempo que transcurre en el hogar y a continuación las actividades que realizan fuera de casa.

Los datos obtenidos reflejan que existen diferencias en los hábitos de ocio de los adolescentes según el tipo de actividad o su duración- en función del contexto familiar. En concreto, en lo que respecta al nivel de estudios y a la situación laboral de sus progenitores, así como a la tipología de familia a la que pertenecen, siendo conscientes de que toda generalización conlleva la pérdida de matices sobre las diferencias que existen en el seno de las fami- week from Monday to Friday. First of all, valuing the time at home and then the activities carried out outside the house.

The obtained data reflect that there are differences in their habits of leisure - depending on the type of activity or its duration - according to the family context. In particular, regarding the level of study and the employment status of the parents, and the type of family they belong to, knowing that any generalization involves loss of nuances about the differences that exist inside families. Operated changes during the last deca-

Tabla 2. Tiempo dedicado a distintas actividades de ocio en el hogar, según el nivel de estudios de los padres y las madres (\%)

\begin{tabular}{|c|c|c|c|c|}
\hline \multirow[b]{2}{*}{ Tiempo dedicado a... ${ }^{2}$} & \multicolumn{4}{|c|}{ Estudios de los padres y las madres } \\
\hline & Bajos & Medios & Altos & $x^{2}$ \\
\hline Juegos electrónicos & 33,9 & 25,1 & 19,4 & $29,74^{* * *}$ \\
\hline Chatear / Redes Sociales & 41,2 & 36,7 & 27 & $30,58^{* * *}$ \\
\hline Leer & 9,3 & 11,3 & 11,3 & $10,75^{* *}$ \\
\hline Estar con la familia & 65,7 & 57,7 & 54,8 & $14,65^{* *}$ \\
\hline Teléfono Móvil & 18,2 & 15 & 10,9 & $32,35^{* * *}$ \\
\hline No hacer nada & 12,7 & 9,6 & 6,4 & $13,67^{* *}$ \\
\hline Ver televisión & 49,7 & 42,4 & 33,7 & $41,99^{* * *}$ \\
\hline $\begin{array}{l}1 \text { Prueba de Kruskal-Wallis. } \\
2 \text { Porcentaje de adolescentes } \\
{ }^{* *} \text { p }<0,001 ; \text {; }{ }^{* * *} \text { p }<0,001 \\
\text { Fuente: Proyecto TETOSO (cć }\end{array}$ & Elaboración & vidades descrit & & \\
\hline
\end{tabular}

Table 2. Time spent on different leisure activities at home, according to parents' level of education (\%). $(\mathrm{N}=3306,2010-2011)$

\begin{tabular}{lrrrr}
\hline & \multicolumn{3}{c}{ Parents level of education } \\
\hline Time devoted to... & Low & Medium & High & $\mathbf{X}^{\mathbf{2}}$ \\
\hline Electronics games & 33,9 & 25,1 & 19,4 & $29,74^{* * *}$ \\
\hline Chat / Social Network & 41,2 & 36,7 & 27 & $30,58^{* * *}$ \\
\hline Read & 9,3 & 11,3 & 11,3 & $10,75^{* *}$ \\
\hline Spend time with family & 65,7 & 57,7 & 54,8 & $14,65^{* *}$ \\
\hline Movile phones & 18,2 & 15 & 10,9 & $32,35^{* * *}$ \\
\hline Doing nothing & 12,7 & 9,6 & 6,4 & $13,67^{* *}$ \\
\hline Watch TV & 49,7 & 42,4 & 33,7 & $41,99^{* * *}$ \\
\hline
\end{tabular}

${ }^{1}$ Kruskal-Wallis Test.

2 Porcentage of teenagers that devote more than one hour to the described activities.

${ }^{* *} \mathrm{p}<0,001 ;{ }^{* * *} \mathrm{p}<0,001$

Source: Proyecto TETOSO (code PSI2008-04308/PSIC). Personal copilation. 
lias. Los cambios operados durante las últimas décadas en el consumo y en las pautas del uso del tiempo libre, influenciados por la crisis económica, han afectado también al ocio en el hogar. Este espacio-tiempo de convivencias, hábitos y pautas de comportamiento cotidianas, circunscrito a ritmos laborales o domésticos de los progenitores, así como a obligaciones educativas y de otra índole de los hijos adolescentes, es nuestro teatro de operaciones en este caso.

Cabe señalar que se observan diferencias significativas en el tiempo que los adolescentes españoles le dedican a lo largo de la semana lectiva al ocio electrónico (video consolas, ordenador, tablets...), cuando se produce más de una hora diaria y según el nivel de estudios de sus progenitores: cuanto mayor es el nivel de estudios de padres y madres, menos tiempo destinan sus hijos adolescentes al ocio con dispositivos electrónicos. Las diferencias en términos porcentuales no son desdeñables, tanto en cuanto un $33,9 \%$ de adolescentes cuyos progenitores no poseen estudios o son primarios, pasan más tiempo de su ocio manipulando este tipo de gadgets. En cambio, disminuye al 19,4 por ciento cuando los cabezas de familia poseen estudios superiores.

Algo semejante ocurre cuando se analizan los porcentajes de adolescentes que "chatean y navegan a través de diferentes redes sociales propias de estos colectivos de edades", siendo superior al $40 \%$ los hijos/as de padres y madres con estudios bajos los que destinan más tiempo a este entretenimiento. En este caso, la diferencia con los hijos/as con padres con estudios altos es casi del doble (27\%). ¿Son los entornos familiares de nivel educativo alto estimulantes para un ocio creativo, antesala del ocio cultural? Es probable que así sea. Ambientes favorecedores de ocio como experiencia humana, activo y no dependiente, inducen el desarrollo de la creatividad (Cuenca, 2009b).

La valoración de otras respuestas, en las que las pantallas también imantan en el disfrute del ocio en el seno del hogar familiar, también revelan diferencias entre los jóvenes con padres sin apenas estudios o básicos y aquellos que sus progenitores disponen de una alta cualificación académico-formativa. El $49,7 \%$ de los primeros declaran ver al menos una hora de televisión al día, frente al 33,7\% de los se- des in the consumption and the free time's usage patterns, influenced by the economic crisis, have also affected leisure time at home. This spacetime of coexistence, habits and daily patterns of behaviour, are confined to labour or domestic rhythms of parents, as well as teenagers' educational obligations and others, which is our area of influence in this case.

It should be noted that there are significant differences on the time that Spanish teens devote during the teaching week to electronic leisure time (video game consoles, computer, tablets...), when it is more than one hour daily and depending on the level of studies of their parents: the higher the level of education of parents and mothers is, the less leisure time spent by their teens in electronic devices. The differences in percentage terms are negligible, as long as $33.9 \%$ of teenagers whose parents do not have studies or are just primary studies spend their leisure time manipulating this type of gadgets. On the other hand, it decreases to $19.4 \%$ when the head of household has higher education.

Something similar happens when analysing the percentages of adolescents who "chat and surf through different social networks of these groups of ages," the children of parents with low studies, are the ones that devoted more time to this entertainment; over $40 \%$ of them. In this case, the difference with the children with parents with high studies is very significant (27\%). Are the family environments of high educational level stimulating for a creative leisure, prelude to the cultural leisure? It is likely to be so. Favourable leisure environments as human, active and non-dependent experience, lead to the development of creativity (Cuenca, 2009b).

Other responses, in which screens also play an important role of the leisure time at home, also reveal differences between young people with parents without studies and those whose parents have a high education. $49.7 \%$ of the first group reveal to watch at least one hour of television per day, compared with $33.7 \%$ of the second group. Technologies have a great influence on how we interact, communicate, socialize, play... and live. For this reason, during the adolescence, the addiction to the devices, virtual re- 
gundos. Las tecnologías ejercen una gran influencia en cómo nos relacionamos, comunicamos, socializamos, jugamos...y vivimos. Por ello, en el caso de la adolescencia, preocupa la dependencia que puede llegar a darse ante los dispositivos, la realidad virtual o la pasividad televisiva. Una evidencia que ha revolucionado todos los aspectos de la vida humana, incluido el ocio de los adolescentes y jóvenes (Lazcano \& Doistua, 2010; Ortega y Bayón, 2014).

De ahí que deban adoptarse medidas socioeducativas que activen la práctica de un ocio más participativo y enriquecedor entre los menores. Sobre todo si se tiene en cuenta su potencial como un ámbito caracterizado "por las acciones con finalidad en sí mismas y por sí mismas" que favorece "la necesidad de saber, obrar, actuar, expresarse o, en definitiva, ser" (Cuenca, 2011b: 21). Por ello, es relevante que en las prácticas cotidianas se tome conciencia del valor del ocio como un tiempo y un espacio que favorece el desarrollo integral de las personas: un proceso de educar para, con y desde el ocio en el que están implicadas todas aquellas personas y entidades que forman parte de la vida de la infancia, de los jóvenes y adolescentes y/o que, en su defecto, toman decisiones que o/y promueven iniciativas que les afectan.

En lo que se refiere al uso del teléfono móvil como herramienta facilitadora de entretenimiento durante la semana lectiva, se observan hasta ocho puntos porcentuales de diferencia en relación a los progenitores que tienen una menor cualificación académica $(18,2 \%)$ y aquellos que disponen de una mejor formación (10,9\%). Entre ambos, siendo un 15\% de la muestra, se encuadran los adolescentes cuyos ascendientes poseen estudios medios. También el "no hacer nada" se incrementa en el grupo cuyos padres cuentan con estudios bajos o medios ( $12,7 \%$ y $9,6 \%$ respectivamente), frente al 6,4 por ciento de los hijos de hogares con mayor nivel de estudios.

La alternativa de la lectura, como opción de ocupación del tiempo libre semanal, adquiere un especial interés. Al contrario de lo que ocurría en ítems presentados anteriormente, se constata que son los hijos de padres y madres con más alta cualificación formativa los que destinan más tiempo a esta práctica (11,3\%), al menos una hora al día. Siendo porcentajes bajos en general, era previsible que estos adolescentes dispusieran de modelos cotidianos ality or the passivity of television is worrying. A evidence that has revolutionized every aspect of human life, including adolescents and youth leisure (Lazcano \& Doistua, 2010; Ortega \& Bayon, 2014).

That is why socio-educational measures must be adopted in order to activate the practice of a more participatory and enriching free time among minors. Especially if considering its potential as a field characterized by "actions with purpose in themselves and by themselves" favouring "the need to know, act, behave, speak, or just be" (Cuenca, 2011b: 21). Therefore, it is essential to be aware, at everyday practices, of the value of leisure as a time and a space to boost an integral development: a process of educating for, with and from the leisure in which all persons and institutions that are part of children, young people and adolescents' life are involved and/or that, alternatively, make decisions and/or promote initiatives affecting them.

Regarding the use of mobile phone as an entertaining tool during the school week, there are up to eight percentage points of difference in relation to parents with lower academic qualifications (18.2\%) and those who have a better education (10.9\%). Between them, $15 \%$ of the sample, we find adolescents whose parents have medium studies. Also "doing nothing" increased in the group whose parents have a low or medium level of studies ( $12.7 \%$ and $9.6 \%$ respectively), facing $6.4 \%$ of children from households with higher level of studies.

The choice of reading, as an option for the free time during the week, acquires a special interest. Contrary to what happened on the above presented items, it is set that they are the children of parents with high educational qualification devoting more time to this practice (11.3\%), at least one hour a day. Even if there are low levels, it was predictable that these teenagers had everyday models that encourage them to read. Whether it is by mimicry or by a conscious educational induction, the fact is no a coincidence.

Apart from the differences that exist at the level of family education, a common pattern in the choice of leisure activities can be observed. A higher percentage of adolescents agrees that the ac-

[ 34 ] JOAO PAULO FERREIRA DELGADO, HÉCTOR POSE PORTO Y ÁNGELA LUCÍA DE VALENZUELA BANDÍN SIPS - PEDAGOGIA SOCIAL. REVISTA INTERUNIVERSITARIA [1139-1723 (2015) 25, 25-49] TERCERA ÉPOCA 
que les inciten a leer. Por mímesis o por una inducción educativa consciente por parte de los adultos en convivencia con los hijos, el dato no es casual.

Más allá de las diferencias que existen en el nivel de estudios de las familias, se observa un patrón común en la elección de las actividades de ocio. Un porcentaje mayor de adolescentes coincide en que la actividad a la que le dedican más tiempo es "estar con la familia", seguido de "ver TV", siendo la lectura la actividad en la que un menor número de chicos y chicas emplean más de una hora. Este último hecho podría corroborar las evidencias del estudio "La cultura de la innovación de los jóvenes españoles en el marco europeo" (Pérez-Díaz y Rodríguez, 2010 en Bas, 2014: 16), que demuestra la inferioridad cultural de los españoles, junto con la ciudadanía portuguesa, italiana y griega. Cabe destacar que todos estos pueblos comparten "una estructura productiva fácil, menos innovación, dificultades para resolver comunes, alfabetización tardía, clientelismo político, corrupción generalizada y una sociedad civil débil"; aspectos que la Pedagogía-Educación Social debe tener en cuenta en sus propuestas e iniciativas socioeducativas.

La situación laboral de los progenitores parece determinante en el tiempo destinado al juego electrónico, a ver la televisión y estar con la familia. Los adolescentes que pertenecen a familias con el padre y la madre sin trabajo, dedican mayor tiempo a las actividades citadas que sus iguales de familias con uno o los dos padres laboralmente activos (véase tabla 3). Es un dato revelador de las dinámicas familiares: que ambos progenitores pasen más tiempo en casa no favorece que sus hijos dediquen menos tiempo al ocio que procuran los dispositivos electrónicos; en todo caso, la precariedad laboral limita significativamente la capacidad adquisitiva de las familias (Blanco, 2006).

Alcanzan términos porcentuales elevados, hasta el $70,3 \%$ de la muestra, el "estar con la familia" en aquellos hogares con ambos progenitores desempleados. No tener la obligación diaria de acudir al trabajo, y, por tanto, de ajustarse a un horario, o no disponer de recursos económicos para un ocio más consumista, induce a pensar que los miembros de estas familias están más tiempo juntos. Al compartir espacio y más tiempo son mayores las oportunidades de realizar alguna actividad lúdica en común. Así, el ítem tivity they devote more time is "being with family", followed by "watching TV", being the reading an activity on which a smaller group of boys and girls spend more than one hour. This last fact could corroborate the evidence of the study "The innovation culture of young Spaniards in the European framework" (Pérez-Díaz and Rodríguez, 2010 en Bas, 2014: !6), which shows the cultural inferiority of the Spaniards, along with Portuguese, Italian and Greek. Note that all these people share "an easy production structure, less innovation, difficulties to solve common, late literacy, patronage system, widespread corruption and a weak civil society"; the Social Pedagogy-Education must take into account those aspects in their socio-educational proposals and initiatives.

The employment status of the parents seems crucial in the time devoted to the electronic games, watching television and being with family. Teens belonging to families with unemployed parents, spend more time engaged in the mentioned activities that their peers from families with one or two occupationally active parent (see table 3). It is a revealing fact of family dynamics: both parents spending more time at home does not favour that their children devote less time to electronic leisure; in any case, the job instability limits the families purchasing power (Blanco, 2006).

"Being with family" reach high values (70.3\%) in those households with both parents' unemployed. Not having the daily obligation to go to work, and, therefore, a schedule, or the lack of financial resources for a more consumerist leisure, suggest that the members of these families spend more time together. By sharing space and more time the chances of doing activities together are higher. Thus, the item "do nothing" only reaches 5.5\% compared with $9 \%$ of parents who are occupationally active. 
Tabla 3. Tiempo dedicado a distintas actividades de ocio, según la situación laboral de los progenitores (\%) $(\mathrm{N}=3306,2010-2011)$

\begin{tabular}{|c|c|c|c|c|}
\hline \multirow[b]{2}{*}{ Tiempo dedicado a... ${ }^{2}$} & \multicolumn{4}{|c|}{ Situación laboral $^{1}$} \\
\hline & Ninguno trabaja & Uno trabaja & Ambos trabajan & $x^{2}$ \\
\hline Juegos electrónicos & 31,9 & 27,7 & 23,3 & $14,08^{* * *}$ \\
\hline Chatear / Redes Sociales & 34,7 & 34,5 & 32,9 & 1,76 \\
\hline Leer & 15,3 & 12,4 & 9,9 & 0,32 \\
\hline Estar con la familia & 70,3 & 58,3 & 57 & $6,50^{*}$ \\
\hline Teléfono Móvil & 14,9 & 13,5 & 14,7 & 1,03 \\
\hline No hacer nada & 5,5 & 10,1 & 9 & 2,98 \\
\hline Ver televisión & 50,7 & 45,3 & 38,4 & $12, \mathrm{O} 2^{* *}$ \\
\hline \multicolumn{5}{|c|}{$\begin{array}{l}1 \text { Prueba de Kruskal-Wallis. } \\
2 \text { Porcentaje de adolescentes que dedican más de una hora a realizar las actividades descritas. } \\
{ }^{*} \text { p<O,O5; }{ }^{* *} \text { p<O,OO1; }{ }^{* * *} \text { p }<0,001 .\end{array}$} \\
\hline
\end{tabular}

Tabla 3. Time spent on various leisure activities, according to the employment status of parents (\%) $(\mathrm{N}=3306,2010-2011)$

\begin{tabular}{lcccc}
\hline & \multicolumn{4}{c}{ Employment situation } \\
\hline Time devoted to... & None of them work & One works & Both work & $\mathbf{X}^{\mathbf{2}}$ \\
\hline Electronics games & 31,9 & 27,7 & 23,3 & $14,08^{* * *}$ \\
\hline Chat / Social Network & 34,7 & 34,5 & 32,9 & 1,76 \\
\hline Read & 15,3 & 12,4 & 9,9 & 0,32 \\
\hline Spend time with family & 70,3 & 58,3 & 57 & $6,50^{*}$ \\
\hline Movile phones & 14,9 & 13,5 & 14,7 & 1,03 \\
\hline Doing nothing & 5,5 & 10,1 & 9 & 2,98 \\
\hline Watch TV & 50,7 & 45,3 & 38,4 & $12,02^{* *}$ \\
\hline
\end{tabular}

1 Kruskal-Wallis Test.

2 Percentage of teenagers that devote more than one hour to the described activities.

* $\mathrm{p}<\mathrm{O}, 05 ;{ }^{* *} \mathrm{p}<\mathrm{O}, \mathrm{OO1} ;{ }^{* * *} \mathrm{p}<\mathrm{O}, \mathrm{0O1}$

Source: Proyecto TETOSO (code PSI2008-04308/PSIC). Personal compilation..

"no hacer nada" apenas alcanza el 5,5\% frente al 9\% de los progenitores que están laboralmente activos.

Cabe señalar un hecho positivo al relacionar la situación laboral de los padres-madres con el tipo de ocio de los hijos durante la semana escolar (de lunes a viernes). Se incrementa frente a las demás posibilidades el número de adolescentes que dedican más de una hora al día a "leer" (15,3\%) en el caso de que el padre y la madre estén en paro. Tales índices, siendo escasos, son superiores a cuando uno de los progenitores trabaja $(12,4 \%)$ o lo hacen ambos (9,9\%). Tal vez sea la presencia ejemplarizante de los adultos; quizás se deba a que es más barato
It should be noted a positive fact when linking the employment situation of parents with the kind of entertainment of children during the school week (from Monday to Friday). The number of adolescents who dedicated more than one hour a day to 'read' (15.3\%) in the event that the father and the mother are unemployed, increases regarding the other options. Such index, being low, are higher than when one of the parents $(12.4 \%)$ or both (9.9\%) work. Perhaps due to the exemplary presence of adults; or to the fact that access to reading is cheaper (through libraries or copies available at home) than to another type of recre-

[ 36 ] JOAO PAULO FERREIRA DELGADO, HÉCTOR POSE PORTO Y ÁNGELA LUCÍA DE VALENZUELA BANDÍN SIPS - PEDAGOGIA SOCIAL. REVISTA INTERUNIVERSITARIA [1139-1723 (2015) 25, 25-49] TERCERA ÉPOCA 
Tabla 4. Tiempo dedicado a distintas actividades de ocio, según la tipología familiar (\%). (N=3306, 2010-2011)

\begin{tabular}{|c|c|c|c|}
\hline \multirow[b]{2}{*}{ Tiempo dedicado a... ${ }^{2}$} & \multicolumn{3}{|c|}{ Tipo de familia ${ }^{1}$} \\
\hline & Nuclear & Monoparental & $x^{2}$ \\
\hline Juegos electrónicos & 24,4 & 31,0 & $-2,67^{* *}$ \\
\hline Chatear / Redes Sociales & 32,9 & 40,0 & $-3,62^{* * *}$ \\
\hline Leer & 10,2 & 13,6 & $-0,38$ \\
\hline Estar con la familia & 57,7 & 57,5 & $-0,15$ \\
\hline Teléfono Móvil & 14,2 & 19,2 & $-2,59^{* *}$ \\
\hline No hacer nada & 9,2 & 10,3 & $-1,30$ \\
\hline Ver televisión & 40,1 & 48,6 & $-3,68^{* * *}$ \\
\hline \multicolumn{4}{|c|}{$\begin{array}{l}{ }^{1} \text { Prueba de Mann-Whitney. } \\
2 \text { Porcentaje de adolescentes que dedican más de una hora a realizar las actividades descritas. } \\
{ }^{* *} p<0,001 ;{ }^{* * *} p<0,001\end{array}$} \\
\hline
\end{tabular}

Table 4. Time spent on various activities, according to the family type (\%) (N=3306, 2010-2011)

\begin{tabular}{lccc}
\hline & & Type of family \\
\hline Time devoted to... & Nuclear & Single-parent & $\mathbf{X}^{\mathbf{2}}$ \\
\hline Electronics games & 24,4 & 31,0 & $-2,67^{* *}$ \\
\hline Chat / Social Network & 32,9 & 40,0 & $-3,62^{* * *}$ \\
\hline Read & 10,2 & 13,6 & $-0,38$ \\
\hline Spend time with family & 57,7 & 57,5 & $-0,15$ \\
\hline Movile phones & 14,2 & 19,2 & $-2,59^{* *}$ \\
\hline Doing nothing & 9,2 & 10,3 & $-1,30$ \\
\hline Watch TV & 40,1 & 48,6 & $-3,68^{* * *}$ \\
\hline
\end{tabular}

1 Mann-Whitney Test.

2 Percentage of teenagers that devote more than one hour to the described activities.

${ }^{* *} \mathrm{p}<\mathrm{O}, \mathrm{OO}$; ${ }^{* * *} \mathrm{p}<\mathrm{O}, 001$

Source: Proyecto TETOSO (code PSI2008-04308/PSIC). Personal compilation.

acceder a la lectura (a través de bibliotecas o ejemplares disponibles en el hogar) que a otro tipo de actividades lúdicas que conlleven gasto, el caso es que esta circunstancia positiva -por las virtudes que aporta la lectura- merece destacarse. Con todo, en el actual contexto de crisis económica, es una evidencia tangible que el presupuesto familiar destinado al ocio ha mermado.

También revela interés el cruce de variables que asocia las actividades en el hogar y la tipología familiar (véase tabla 4). En líneas generales, los adolescentes de la muestra que pertenecen a familias ational activities involving expenditure; this is a positive circumstance - by the virtues that provides reading - that deserves to be underlined. However, in the current context of economic crisis, it is a tangible evidence that the family budget devoted to leisure has diminished.

It also interesting to relate variables involving activities in the home and the family typology (see table 4). In general, adolescents in the sample belonging to nuclear families devote significantly less time to electronic leisure than their peers with single-parent families. Similarly, the use of mobile 
Tabla 5. Actividades realizadas en los días de clase y fin de semana (\%). ( $N=3306,2010-2011)$

\begin{tabular}{|c|c|c|c|c|c|c|c|c|c|}
\hline Categorías / Actividades & Ninguno & $\begin{array}{l}1-2 \\
\text { mes }\end{array}$ & $\begin{array}{l}1-2 \\
\text { días }\end{array}$ & $\begin{array}{l}3-4 \\
\text { días }\end{array}$ & $\begin{array}{c}5 \\
\text { días }\end{array}$ & Ninguno & Sábado & Domingo & $\begin{array}{l}\text { Sábado y } \\
\text { Domingo }\end{array}$ \\
\hline \multicolumn{10}{|c|}{ Categoría 1: Asociacionismo y voluntariado } \\
\hline $\begin{array}{l}\text { Participar en asociaciones / } \\
\text { voluntariado }\end{array}$ & 84,8 & 8,7 & 4,6 & 1,4 & 0,4 & 95,0 & 3,0 & 0,8 & 1,1 \\
\hline
\end{tabular}

\section{Categoría 2: Actividades culturales}

\begin{tabular}{lllllllllll}
\hline Ir a música, pintura, etc. & 69,1 & 5,6 & 15,3 & 7,0 & 3,0 & 94,8 & 3,5 & 0,5 & 1,3 \\
\hline Ir al salón de juegos recreativos & 80,5 & 14,4 & 3,5 & 0,9 & 0,7 & 92,7 & 4,2 & 0,8 & 2,2 \\
\hline Ir a clases de baile, danza, ballet, etc. & 84,6 & 2,8 & 7,4 & 3,3 & 2,0 & 96,3 & 2,1 & 0,5 & 1,1
\end{tabular}

\section{Categoría 3: Actividades deportivas}

\begin{tabular}{lllllllllll}
\hline Practicar deporte & 25,4 & 7,5 & 25,2 & 25,3 & 16,6 & 66,0 & 16,0 & 2,8 & 15,3
\end{tabular}

Categoría 4: Actividades asociadas al trabajo escolar

\begin{tabular}{|c|c|c|c|c|c|c|c|c|c|}
\hline Ir a clases particulares & 58,8 & 3,5 & 23,8 & 8,7 & 5,1 & 97,7 & 1,4 & 0,3 & 0,6 \\
\hline \multicolumn{10}{|c|}{ Categoría 5: Actividades de utilización del ciber espacio } \\
\hline Ir al cíber & 87,9 & 6,7 & 3,4 & 1,0 & 1,0 & 94,2 & 3,6 & 0,4 & 1,8 \\
\hline \multicolumn{10}{|c|}{ Categoría 6: Actividades en bares o espacios de diversión } \\
\hline Estar en bares, cafeterías, etc. & 60,4 & 22,8 & 12,2 & 2,6 & 2,0 & 66,9 & 20,4 & 2,9 & 9,8 \\
\hline Salir por la noche & 65,1 & 18,1 & 11,6 & 2,0 & 3,1 & 57,1 & 31,8 & 0,5 & 10,6 \\
\hline Ir al botellón & 83,1 & 11,7 & 3,4 & 0,7 & 1,1 & 78,6 & 17,9 & 0,4 & 3,1 \\
\hline
\end{tabular}

\section{Categoría 7: Otras actividades de tiempo libre}

\begin{tabular}{lcccccccccc}
\hline Estar con amigos y amigas & 33,4 & 10,3 & 30,8 & 12,3 & 13,1 & 31,6 & 27,6 & 1,5 & 39,3 \\
\hline Jugar en la calle, parque, etc. & 60,7 & 13,8 & 15,7 & 4,9 & 4,9 & 72,6 & 9,1 & 2,5 & 15,8 \\
\hline Estar en la calle, parque, etc. & 44,0 & 12,4 & 24,4 & 9,8 & 9,3 & 50,0 & 17,9 & 2,5 & 29,6 \\
\hline Ir de tiendas o de compras & 35,4 & 43,9 & 15,2 & 2,8 & 2,7 & 70,2 & 23,0 & 1,5 & 5,3 \\
\hline Caminar o pasear & 37,9 & 20,6 & 19,9 & 8,3 & 13,2 & 72,2 & 7,6 & 5,4 & 14,8 \\
\hline Practicar algún hobby & 35,6 & 10,0 & 21,1 & 14,9 & 18,4 & 66,3 & 10,4 & 3,9 & 19,5 \\
\hline
\end{tabular}

Fuente: Proyecto TETOSO (código PSI2008-04308/PSIC). Elaboración propia.

nucleares dedican significativamente menos tiempo al ocio a través de pantallas que sus iguales con familias monoparentales. De igual modo, el empleo del móvil, la participación en chats-redes sociales o ver TV, se ve afectado según el tipo de familia.

Excepto en la opción "estar con la familia", cuyos porcentajes son casi idénticos, alrededor del 57 por ciento, en todas las demás alternativas lúdicas, los datos relativos a los adolescentes pertenecientes a familias con un solo progenitor superan a las que presentan un perfil más clásico. En unas etapas del desarrollo evolutivo en la que son esenciales las referencias adultas estables, la presencia o ausencia phones, participation in social networks-chat or watch TV, is affected by type of family.

Except in the option "being with family", whose percentages are almost identical, around 57 per cent, in all other leisure alternatives. Data of adolescents belonging to families with one parent exceed those with a more classic profile. In some stages of the evolutionary development, in which stable adult references are essential, the presence or absence of an adult in the daily live of teens at home is likely to be an influential variable in the type or, at least, in the circumstances that their leisure time occurs. 
Table 5. Activities carried out in school days and weekend (\%)

\begin{tabular}{|c|c|c|c|c|c|c|c|c|c|}
\hline Categories / Activities & None & $\begin{array}{c}1-2 \\
\text { month }\end{array}$ & $\begin{array}{l}1-2 \\
\text { days }\end{array}$ & $\begin{array}{l}3-4 \\
\text { days }\end{array}$ & $\begin{array}{l}5 \\
\text { days }\end{array}$ & None & $\begin{array}{l}\text { Satur- } \\
\text { days }\end{array}$ & Sundays & $\begin{array}{l}\text { Saturdays } \\
\text { and Sundays }\end{array}$ \\
\hline \multicolumn{10}{|c|}{ Category 1: Associativity and volunteering } \\
\hline $\begin{array}{l}\text { Participate in associations / } \\
\text { volunteer }\end{array}$ & 84,8 & 8,7 & 4,6 & 1,4 & 0,4 & 95,0 & 3,0 & 0,8 & 1,1 \\
\hline
\end{tabular}

Category 2: Cultural activities

\begin{tabular}{lllllllllll}
\hline Play music, paint, etc. & 69,1 & 5,6 & 15,3 & 7,0 & 3,0 & 94,8 & 3,5 & 0,5 & 1,3 \\
\hline Go to a recreational area & 80,5 & 14,4 & 3,5 & 0,9 & 0,7 & 92,7 & 4,2 & 0,8 & 2,2 \\
\hline Dancing or ballet lessons, etc. & 84,6 & 2,8 & 7,4 & 3,3 & 2,0 & 96,3 & 2,1 & 0,5 & 1,1 \\
\hline
\end{tabular}

Category 3: Sport activities

\begin{tabular}{lllllllllll}
\hline Practice sport & 25,4 & 7,5 & 25,2 & 25,3 & 16,6 & 66,0 & 16,0 & 2,8 & 15,3
\end{tabular}

Category 4: School related activities

\begin{tabular}{|c|c|c|c|c|c|c|c|c|c|}
\hline Private lessons & 58,8 & 3,5 & 23,8 & 8,7 & 5,1 & 97,7 & 1,4 & 0,3 & 0,6 \\
\hline \multicolumn{10}{|c|}{ Category 5: Cyber space activities } \\
\hline Go to a cyber coffee & 87,9 & 6,7 & 3,4 & 1,0 & 1,0 & 94,2 & 3,6 & 0,4 & 1,8 \\
\hline \multicolumn{10}{|c|}{ Category 6: Activities in bar sor entertainment places } \\
\hline Bars, cafeterias, etc. & 60,4 & 22,8 & 12,2 & 2,6 & 2,0 & 66,9 & 20,4 & 2,9 & 9,8 \\
\hline Going out at nights & 65,1 & 18,1 & 11,6 & 2,0 & 3,1 & 57,1 & 31,8 & 0,5 & 10,6 \\
\hline Open-air drinking & 83,1 & 11,7 & 3,4 & 0,7 & 1,1 & 78,6 & 17,9 & 0,4 & 3,1 \\
\hline
\end{tabular}

\section{Category 7: Other free time activities}

\begin{tabular}{lcccccccccc}
\hline Spend time with friends & 33,4 & 10,3 & 30,8 & 12,3 & 13,1 & 31,6 & 27,6 & 1,5 & 39,3 \\
\hline Play outside in the streets, parks, etc. & 60,7 & 13,8 & 15,7 & 4,9 & 4,9 & 72,6 & 9,1 & 2,5 & 15,8 \\
\hline Spend time outside & 44,0 & 12,4 & 24,4 & 9,8 & 9,3 & 50,0 & 17,9 & 2,5 & 29,6 \\
\hline Go shopping & 35,4 & 43,9 & 15,2 & 2,8 & 2,7 & 70,2 & 23,0 & 1,5 & 5,3 \\
\hline Walking & 37,9 & 20,6 & 19,9 & 8,3 & 13,2 & 72,2 & 7,6 & 5,4 & 14,8 \\
\hline Practice a hobby & 35,6 & 10,0 & 21,1 & 14,9 & 18,4 & 66,3 & 10,4 & 3,9 & 19,5 \\
\hline
\end{tabular}

Source: Proyecto TETOSO (code PSI2008-04308/PSIC). Personal compilation.

de un adulto en la cotidianeidad de los adolescentes en el hogar es probable que sea una variable influyente en las características o, al menos, en las circunstancias que concurren en dicho ocio.

Resulta evidente que la responsabilidad en el ámbito privado de la calidad del ocio adolescente es, en gran medida, de las propias familias; requiriéndose una actitud permanente y crítica por parte de los adultos presentes en las mismas. De ahí que, fruto de la instauración de una preconcepción negativa de los hábitos de ocio de la adolescencia, las preocupaciones y demandas familiares se traduzcan en la solicitud de políticas activas por parte de las Ad-
It is clear that responsibility in the private sphere of the quality of the teen entertainment is largely of families; requiring a permanent and critical attitude by adults present in them. Hence, as a result of the establishment of negative preconception habits of adolescence leisure, the concerns and demands of family turn into the request of active policies by the Government and its institutions (Monteagudo, 2004).

The way of organise and use of leisure time are important indicators when it comes to see if the performed activities promote the personal and social enrichment or, on the contrary, hinder the 
ministraciones Públicas y sus instituciones (Monteagudo, 2004).

Los modos de organizar y utilizar los tiempos de ocio son indicadores importantes cuando se trata de observar si las actividades realizadas promueven el enriquecimiento personal y social o, por el contrario, dificultan la inclusión cultural. Para operativizar el análisis de los datos dividimos las actividades por categorías, atendiendo al contenido de las preguntas formuladas, en actividades de voluntariado, culturales, deportivas, asociadas al trabajo escolar, a la utilización del cíber espacio, a frecuentar bares o espacios de diversión y a otras actividades de ocupación de sus tiempos libres. Las categorías aparecen reflejadas en la tabla 5.

Un primer análisis permite concluir que existen diferencias en la selección de las actividades de ocio y en el tiempo que emplean en cada una de ellas. Así, la participación en actividades de voluntariado o apoyo social ofrece una expresión reducida en los días de semana -de lunes a viernes- toda vez que el $84,8 \%$ de la muestra no les dedica ningún tiempo. Apenas el 4,6\% de los estudiantes las realizan 1 ó 2 días a la semana, siendo aún menos los que lo hacen entre 3 y 4 días (un 1,4\%). Cabría esperar una alteración en el fin de semana, al tratarse de un período que permite una utilización más diversificada del tiempo, pero los datos acentúan esta tendencia (95\%).

Las iniciativas con un enfoque solidario favorecen la adquisición de aprendizajes de carácter cultural, contribuyen a la inclusión social y al desarrollo de un sentimiento de implicación en relación al otro, sea un individuo, un grupo o una comunidad. En el grupo estudiado estamos en un campo casi inexplorado, que puede potenciar la cohesión y la educación social, ya que "construir comunidad exige interesarse por lo que sucede en el entorno próximo, y participar en las diversas dinámicas sociales orientadas a crear oportunidades para la práctica de la solidaridad colectiva y el ejercicio de la responsabilidad individual en función del bien común" (Morán, Iglesias, Vargas y Rouco, 2012: 95).

El contacto con las expresiones artísticas alienta la vivencia del ocio activo y enriquecedor, que promueve la creatividad y el espíritu crítico. Las actividades culturales desarrolladas fuera del tiempo escolar, como la música y la pintura, ocupan al 30,9\% cultural inclusion. To perform the data analysis we have divided activities into categories, according to the questions asked, in volunteer activities, cultural, sports, associated with school work, the use of the cyberspace, go to bars or leisure areas and other occupations for their spare time. The categories are set in table 5 .

A first analysis leads to the conclusion that there are differences in the leisure activities' selection and in the time spend on each of them. Thus, participation in volunteer activities or social support is reduced during the week - Monday to Friday - given that $84.8 \%$ of the sample do not devote them any time at all. Only $4.6 \%$ of students perform them once or twice a week, even fewer do it 3-4 days (1.4\%). An alteration in the weekend would be expected, given that it is a period that allows a more diversified use of time, but data accentuate this trend (95\%).

Solidarity-based initiatives favour cultural learning's acquisition, contribute to the social inclusion and the development of an involvement feeling in relation to the other, either to a subject, a group or a community. In the study group are in a nearly unexplored field, which can enhance the cohesion and social education, since "build a community requires to be interested in what happens in the immediate surroundings, and participate in various social dynamics focused on creating opportunities for the practice of collective solidarity and the exercise of individual responsibility on the basis of the common good" (Morán, Iglesias, Vargas and Rouco, 2012: 95).

Contacting with the artistic expression encourage experience of an enriching and active leisure, which promote creativity and critical thinking. Cultural activities outside the school, such as music and painting, compiles $30.9 \%$ of the students, while $5.6 \%$ of this group barely do it once or twice a month. $25.3 \%$ of them perform those activities regularly in their leisure time. Dance or ballet lessons are less popular, since just 12.7 percent spend their weekly time in them. On the other hand, the recreational games room is not widely used during the week: 80.5 per cent do not come to them and $14.4 \%$ just goes 1 or 2 times a month. It is not an important activity during weekend as just a $7.2 \%$ declares to go on Saturday, Sunday or on both days.

[ 40 ] JOAO PAULO FERREIRA DELGADO, HÉCTOR POSE PORTO Y ÁNGELA LUCÍA DE VALENZUELA BANDíN 
de los estudiantes, a pesar de que el 5,6\% de este grupo apenas lo hace 1 ó 2 veces al mes. Para el $25,3 \%$ estamos ante actividades que son practicadas regularmente en el tiempo de ocio. Las clases de baile, danza o ballet son menos realizadas, ya que apenas el 12,7 por ciento afirma ocupar su tiempo semanal en ellas. Por otro lado, el salón de juegos recreativos no es muy utilizado en su tiempo entre semana: el 80,5 por ciento no lo frecuenta y el $14,4 \%$ apenas lo hace 1 ó 2 veces al mes. En el fin de semana tampoco se revela una gran dedicación a esta actividad, pues apenas un $7,2 \%$ declara frecuentarlos el sábado, domingo o en ambos días.

El deporte, uno de los ámbitos principales del ocio es, por el contrario, una actividad popular para la muestra objeto de estudio: sólo el $25,4 \%$ de los menores manifiestan no practicar ejercicio físico durante la semana y el 50,5\% sí lo hacen regularmente, desde 1 a 4 días, mientras que un $16,6 \%$ practica deporte todos los días de la semana. La tendencia se invierte en el fin de semana, de modo que el $66 \%$ de los estudiantes no le dedica tiempo a esta actividad. A pesar de ello, el deporte es una práctica de las más desarrolladas durante el fin de semana. Puede explicarse por el bajo costo que supone la práctica de ciertas modalidades deportivas y la diseminación de infraestructuras existentes, que facilitan el acceso, sobre todo en el ámbito municipal.

La categoría de las actividades relacionadas con el trabajo escolar incluye una pregunta sobre la frecuencia de acudir a clases de refuerzo. Un 58,8\% de los estudiantes no sabe o no contesta, frente a un $37,6 \%$ que sí acuden a ellas: el 23,8 por ciento uno o dos días por semana; el 8,7\% entre 3-4 días; y el 5,1\% los cinco días de la semana. Datos preocupantes que indican una dedicación excesiva al trabajo académico y una sobrecarga de actividades escolares que comprometen el ejercicio de derechos esenciales, como el disponer de tiempo libre, para la convivencia con amigos y familiares o descansar. Es la influencia de los tiempos escolares en los tiempos sociales, determinantes en los modos de organización del ocio cotidiano (Caride, Lorenzo y Rodríguez, 2012). Felizmente, el fin de semana, desde hace décadas un tiempo de ocio y descanso, es un período sin clases particulares para casi la totalidad de los estudiantes. De hecho, apenas el 2,3\% lleva a cabo esta actividad.

Los datos recogidos acerca de las actividades que
On the contrary, sport (one of the main areas of leisure) is a popular activity for the sample under study: only $25.4 \%$ of children practice no physical exercise during the week and $50.5 \%$ do it regularly, from 1 to 4 days, while a $16.6 \%$ practice sport every day of the week. The trend is reversed at the weekend, so that $66 \%$ of students do not dedicate time to this activity. In spite of this, the sport is one of the more developed activities during the weekend. It can be explained because it is quite cheap to practice some sports and due to the existence infrastructures, which facilitate its access, especially at the municipal level.

There is a question regarding private lessons frequency at school level. 58.8\% of the students do not know or have no reply, compared with $37.6 \%$ that do come to them: the $23.8 \%$ just one or two days per week; $8.7 \%$ between 3-4 days; and $5.1 \%$ the five days a week. Those are worrying data reflecting an excessive devotion to academic work and overcharging of school activities which limits the exercise of essential rights, as the availability of free time, spend time with friends and relatives or rest. The influence of school time in social times is decisive in how to organize the daily leisure (Caride, Lorenzo and Rodríguez, 2012). Happily, the weekend (for decades a time for leisure and relaxation) is a period without private lessons for almost all students, just $2.3 \%$ of them.

The collected data about the activities involving the use of a cyber reveal that, in accordance with the answers given, $87.9 \%$ do not go during the week and just $5.4 \%$ perform this activity on a regular basis. This trend is accentuated in the weekend: $94.2 \%$ of students says not to use it, despite of being a period with more free time and less subject to mandatory activities and routines. These results would be surprising years ago, according to the interest in the Internet usage and the access to social networks, of this particular group of age. But nowadays, they are more and more households that have digital devices enabling to spend the leisure time at home without going to public spaces for this. According to Caride, Lorenzo and Rodríguez (2012: 28) our teens do not face the communicational tech- 
comportan la utilización de un cíber revelan que, de acuerdo con las respuestas expresadas, el $87,9 \%$ no lo frecuentan durante la semana y apenas un $5,4 \%$ se dedican a esta actividad con regularidad. Esta tendencia se acentúa en el fin de semana: el 94,2\% de los estudiantes declara no utilizarlo, a pesar de ser un período con más tiempo libre y menos sujeto a rutinas y actividades obligatorias. Estos resultados serían sorprendentes hace años, atendiendo al interés que la utilización de internet y el acceso a las redes sociales despierta, en este grupo de edad particularmente. Pero hoy en día, son cada vez más los hogares que disponen de dispositivos para ocupar el tiempo de ocio en formato digital, sin tener que acudir a espacios públicos especializados para ello. Como observan Caride, Lorenzo y Rodríguez (2012: 28), nuestros adolescentes no se sitúan ante las tecnologías comunicacionales "de forma pasiva, sino que son activas en la recepción y transmisión de los mensajes, productores de significados que inciden cotidianamente en sus estilos de vida".

La categoría que refleja la estancia en bares o espacios nocturnos de diversión, pone de relieve que durante la semana, un 60,4\% de los adolescentes manifiestan no acudir a bares, cafeterías o pubs y que un $22,8 \%$ apenas lo hacen 1 ó 2 veces al mes. Durante el fin de semana, el 66,9\% no van a estos espacios, mientras que el $20,4 \%$ lo hacen el sábado y el 9,8\% también el domingo. Tendencias similares se registran en salir por la noche durante la semana, con valores ligeramente inferiores a la frecuencia con la que acuden a cafeterías, bares o pubs, a pesar de que un pequeño grupo (3,1\%) afirma salir todas las noches. En el fin de semana se incrementa el número de los que salen el sábado (31,8\%) y el sábado y domingo (10,6\%).

El botellón no ocupa el tiempo libre del $83,1 \%$ de los estudiantes en los días de semana. Para el 11,7\%, apenas lo hace una o dos veces al mes. Son una minoría $(5,2 \%)$ los que van al botellón con regularidad, mereciendo una reflexión especial la situación de los 24 estudiantes que lo hacen entre 3 y 4 días por semana y los 34 que afirman hacerlo todos los días de la semana. Es en el fin de semana cuando aumenta ligeramente el número de los que participan en el botellón, siendo el sábado cuando los adolescentes de la muestra emplean más tiempo en esta actividad (17,9\%); el valor de los que nunca lo hacen en estos días equivale al 78,6 por ciento. nologies "passively, but they are active in the reception and transmission of messages, and are producers of meanings with an impact on their daily lifestyles".

The category of spending time at bars or entertaining night places, highlights that during the week, a $60.4 \%$ of teens don't go to bars, cafés or pubs and $22.8 \%$ just go once or twice a month. During the weekend, $66.9 \%$ do not go to these places, while $20.4 \%$ do it on Saturdays and the $9.8 \%$ also on Sundays. Similar trends are recorded in relation to going out at night during the week, with slightly lower values to the frequency of going to cafeterias, bars and pubs, while a small group (3.1\%) says to go out every night. The number of those going out is higher at the weekend; $31.8 \%$ just on Saturdays and (10.6\%) on Saturdays and Sundays.

The open-air drinking does not occupy the free time of $83.1 \%$ of the students in the weekdays. $11.7 \%$ of them just do it once or twice a month. A minority (5.2\%) are those who go to the open-air drinking regularly, we can highlight 24 students which do so between 3 and 4 days per week and 34 of them that claim to do it every day of the week. During the weekend the number of those involved in the open-air drinking slightly increases, being on Saturdays when adolescents of the sample spend more time in this activity (17.9\%); a $78.6 \%$ of them claim that they never do it during in these days.

We talk about a field in which leisure is mixed with consumption behaviours, sometimes in an ambiguous way, combining situations that can, contradictorily, lead to the risk or the indispensable coexistence with their peers. Adolescence is a time in which the identity and autonomy acquisition emerges, friendly relations are developed, love relationships begin and begin to discover new spaces, i.e., a key moment in the establishment of affective and social bonds. A period characterized by challenging the rules and questioning established habits and mindsets. In the perspective of community-building, according to Morán, Iglesias, Vargas and Rouco (2012: :90), "it is essential that adolescents have time enough to live relationships not based on the obligation of school life, so they can create

[ 42 ] JOAO PAULO FERREIRA DELGADO, HÉCTOR POSE PORTO Y ÁNGELA LUCÍA DE VALENZUELA BANDíN SIPS - PEDAGOGIA SOCIAL. REVISTA INTERUNIVERSITARIA [1139-1723 (2015) 25, 25-49] TERCERA ÉPOCA 
Aludimos a un ámbito en el que lo lúdico se mezcla con los comportamientos de consumo, en ocasiones de modo ambiguo, donde se combinan tensiones que pueden, contradictoriamente, propiciar el riesgo o la indispensable convivencia con sus iguales. La adolescencia es un tiempo en el que surge la conquista de la identidad y la autonomía, se desarrollan las relaciones de amistad, se inician las relaciones amorosas y comienzan a frecuentarse nuevos espacios, es decir, un momento clave en el establecimiento de vínculos afectivos y sociales. Un período caracterizado por desafiar las reglas y cuestionar los hábitos y modos de pensar establecidos. En la perspectiva de construcción de la comunidad, reivindicada por Morán, Iglesias, Vargas y Rouco (2012: 90), "es fundamental que los adolescentes tengan el tiempo suficiente para experimentar relaciones alejadas del sentido de obligatoriedad que supone la vida escolar, de forma que puedan estructurar sus propios grupos de referencia que aseguren el bienestar individual derivado de la convivencia equilibrada con los otros". Las conductas inadaptadas en la adolescencia surgen normalmente asociadas a estilos de ocio que empobrecen la creatividad, el espíritu crítico y la integración cultural.

En la última categoría agrupamos un conjunto diversificado de "otras" actividades asociadas al tiempo de ocio. En este grupo, lo que más ocupa su tiempo es convivir con los amigos y amigas fuera del centro escolar, convergente con el incremento progresivo de las relaciones con los pares, seguida de cerca por el tiempo empleado en hacer compras, en hobbies y en caminar o pasear. La actividad menos realizada es jugar en la calle o en el parque. La utilización del tiempo en el fin de semana no sufre cambios significativos.

En definitiva, las actividades adscritas a la categoría 'actividades en bares o espacios nocturnos de diversión' es el único ítem en el que se verifica una mayor intensidad de la ocupación en los tiempos del fin de semana. En las restantes, o no se nota un aumento en los días lectivos o se registra, por el contrario, una disminución durante el fin de semana.

Uno de los objetivos del estudio residía en saber si existe alguna relación significativa entre la edad y el tipo de actividades que realizan los estudiantes. En el gráfico 1, se exponen las actividades realizadas y las diferencias que se dan entre ellas.

Identificamos cuatro parámetros o tendencias en las actividades realizadas y en cómo cambian de acuer- their own reference groups that ensure their wellbeing derived from coexistence with others". Inappropriate behaviours in adolescence are normally associated to styles of leisure activities, which deplete the creativity, critical thinking and cultural integration.

In the last category we grouped a diversified set of "other" activities associated with leisure time. In this group, which occupies most of their time is to spend time with friends off the school, as well as the progressive increase in relationship with their peers, closely followed by time spent in shopping, in hobbies and on walking. The less performed activity is playing in the street or in the park. These time organization it is similar during the weekend.

So, activities assigned to the category ' activities in bars or entertaining night places' is the only item that has a proved higher intensity during the weekend. The rest, either its increment is not noticed during school days, or decreases during the weekend.

One of the objectives of the study was to know if there was any significant relationship between age and the type of activities carried out by the students. Figure 1 outlines the activities carried out and the differences between them.

We identified four parameters or trends in the developed activities and how they change by age: the first, increasing, when activity increases as respondents are older; the second, decreasing, in the opposite direction; the third, a consistent trend, which does not register a significant alteration in accordance with ages studied; and, last, a fickle trend, when the ups and downs are interspersed.

Certainly there are significant relationships between age and the activities described, except: being with friends outside the school $\left(X^{2}\right.$ $(5)=7,939, p=0,160)$; stay outside $\left(X^{2}(5)=9,363\right.$, $p=0$, 095); go shopping $\left(X^{2}(5)=9,246, p=0\right.$, $100)$; go to the cyber $\left(X^{2}(5)=2,976, p=0,704\right)$; go to dance lessons or ballet classes $\left(X^{2}(5)=\right.$ $9,372, p=0$, 095) and practice a hobby $\left(X^{2}(5)=\right.$ 2,592, $p=0,763$ ).

With the same categories that were used to study the activities carried out in the days of classes and at the weekends (table 5 ) in voluntary ac- 
Gráfico 1. Actividades realizadas por edades (\%). (N=3306, 2010-2011)

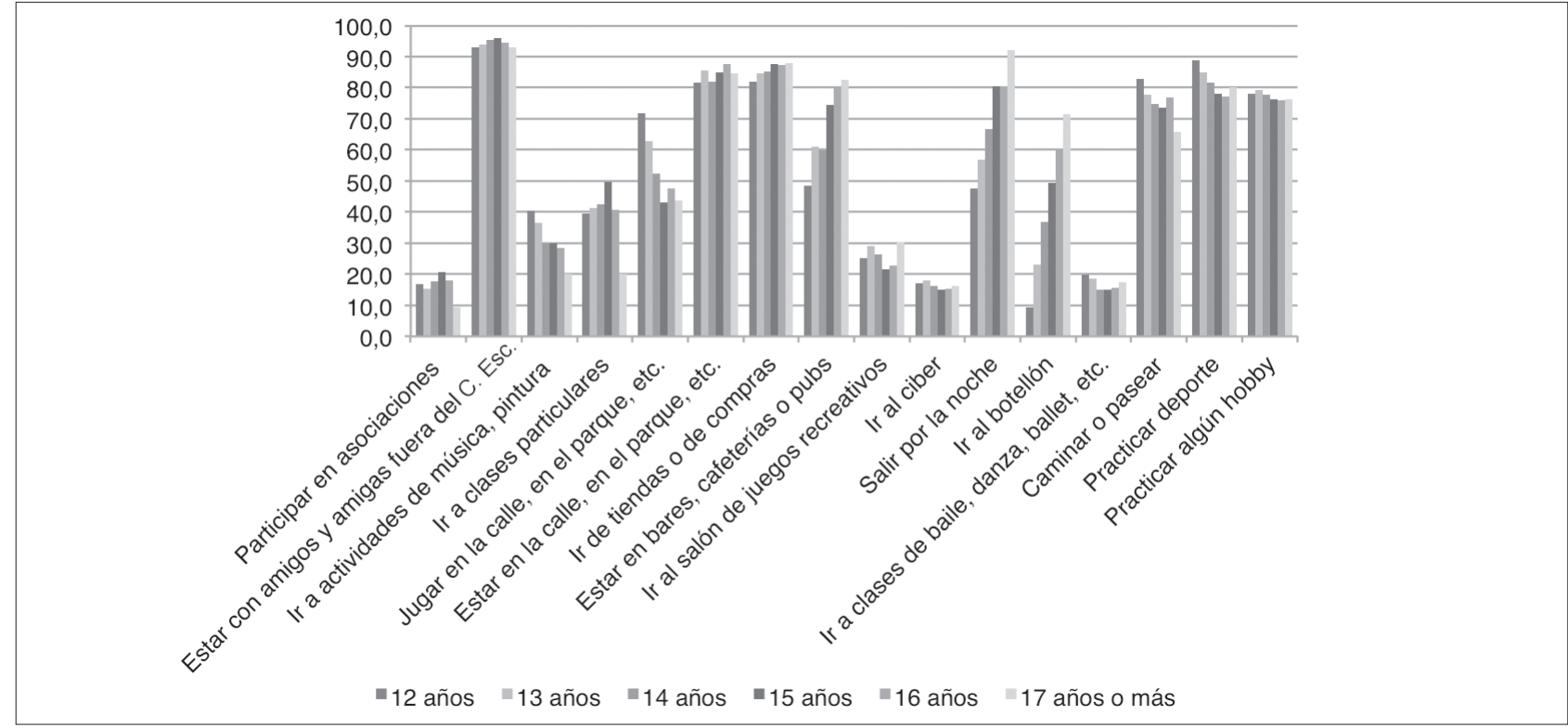

Fuente: Proyecto TETOSO (código PSI2008-04308/PSIC). Elaboración propia.

Graph 1. Activities by Age (\%). (N=3306, 2010-2011)

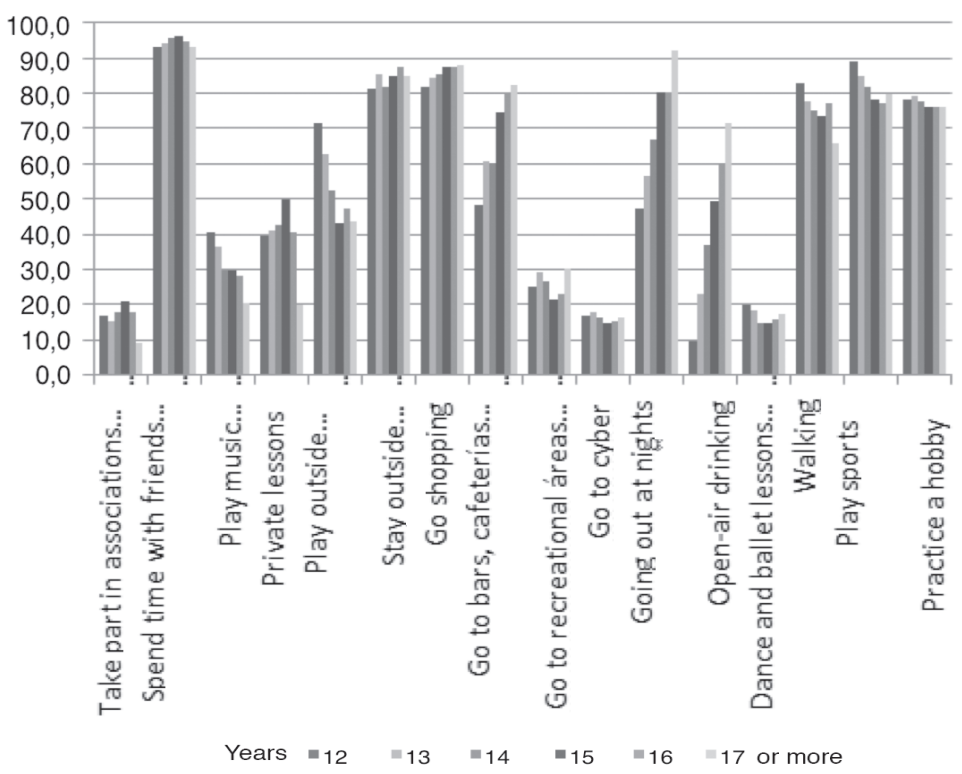

Source: Proyecto TETOSO (code PSI2008-04308/PSIC). Personal compilation.

do con la edad: la primera, ascendente, cuando la actividad aumenta conforme los entrevistados tienen mayor edad; la segunda, descendente, en sentido contrario; la tercera, una tendencia constante, en la que no se registra una alteración significativa de acuerdo con las edades estudiadas; $y$, la última, una tendencia inconstante, cuando las subidas y descensos se intercalan.

Ciertamente existen relaciones significativas entre la edad y las actividades descritas, exceptuando: estar con amigos/as fuera del centro $\left(X^{2}(5)=7,939, p=0,160\right)$; tivities an inconsistent trend is perceived, with a maximum of time occupation at the age of 15 and a significant decrease at the age of 17 or more. Cultural activities decrease; music and painting are a range of inconsistent in relation to the games room, which decreases at 13 years to climb from 16 years, as it happens with dance or ballet lessons, which decreases from 12 to 14 years and increase from this age.

Sport presents a descending profile, with the exception of 17 years or more, when it increases.

[ 44 ] JOAO PAULO FERREIRA DELGADO, HÉCTOR POSE PORTO Y ÁNGELA LUCÍA DE VALENZUELA BANDíN SIPS - PEDAGOGIA SOCIAL. REVISTA INTERUNIVERSITARIA [1139-1723 (2015) 25, 25-49] TERCERA ÉPOCA 
estar en la calle, en el parque, etc. $\left(X^{2}(5)=9,363\right.$, $p=0,095)$; ir de tiendas o de compras $\left(X^{2}(5)=9,246\right.$, $p=0,100)$; ir al cíber $\left(X^{2}(5)=2,976, p=0,704\right)$; ir a clases de baile, danza, ballet, etc. $\left(X^{2}(5)=9,372, p=0,095\right)$ y practicar algún hobby $\left(X^{2}(5)=2,592, p=0,763\right)$.

Con las mismas categorías que fueron utilizadas para estudiar las actividades realizadas en los días de clases y en el fin de semana (tabla 5) en las actividades de voluntariado se percibe una tendencia inconstante, con un máximo de ocupación del tiempo a los 15 años y un descenso significativo en la franja de edad de los 17 años o más. Las actividades culturales ofrecen un sesgo descendente; la música o la pintura están en un intervalo inconstante en relación al salón de juegos recreativos, que decrece a los 13 años para volver a subir a partir de los 16, como es el caso de las clases de baile, danza o ballet, que disminuye de los 12 a los 14 años para incrementarse a partir de esta edad.

El deporte presenta un perfil descendente, a excepción de los 17 años o más, en que vuelve a aumentar. Por otro lado, la frecuencia en la asistencia a clases particulares asociadas al trabajo escolar, revela una tendencia inconstante, aumentando hasta los 15 años y decayendo en las edades siguientes. La utilización del cíber espacio es constante, pues registra valores semejantes en todas las edades.

Las prácticas que implican acudir a bares o espacios de diversión registran un perfil ascendente en las tres actividades analizadas, en especial la participación en el botellón. Finalmente, en lo que se refiere a las otras actividades de ocupación del tiempo libre, la mayor parte de las que han sido estudiadas son constantes, sin que presenten alteraciones significativas de acuerdo con la edad. Así sucede cuando se trata de estar con amigos y amigas fuera del centro escolar, estar en la calle o en el parque, ir de compras o el practicar algún hobby. Las restantes actividades reflejan una tendencia descendente, más acentuada en lo relativo a jugar en la calle o en el parque que en caminar o pasear.

\section{Conclusiones}

Hemos detectado diferencias significativas en el tiempo que los adolescentes españoles le dedican más de una hora diaria, a lo largo de la semana lectiva, al ocio electrónico según el nivel de estudios de sus progenitores. De modo general, cabe inferir que cuanto
On the other hand, the frequency of attendance at tutorials associated with school work, reveals an inconstant trend, increasing until 15 years old and decreasing in the following years. The use of the cyber space is constant, because such values are recorded in all ages.

Practices that involve going to bars or entertaining places recorded a rising profile in the three analysed activities, in particular participation in open-air drinking. Finally, regarding other leisure time activities, most of the studied remain stable, unless those presenting significant alterations according to age. This is the case of spending time with friends outside the school, spend time outside, go shopping or practising a hobby. The remaining activities reflect a downward trend, more pronounced in relation to play in the street or in the park than in walking.

\section{Conclusions}

We have detected significant differences in the time that Spanish teens devote more than one hour a day, during school days, to electronic leisure according to the level of studies of their parents. In general, it should be inferred that the 
mayor es el nivel de estudios de aquellos, menos tiempo destinan sus hijos adolescentes al ocio con dispositivos electrónicos. Algo semejante ocurre si observamos los porcentajes de adolescentes que chatean y navegan a través de diferentes redes sociales.

Cabe destacar que, con independencia de las diferencias que existen en función del nivel de estudios de las familias, se observa un patrón común en la elección de las actividades de ocio. La situación laboral de los progenitores solo es determinante para el tiempo destinado al juego electrónico y a ver la televisión.

Por último, señalar que son muchas las evidencias que sugieren que la edad de los adolescentes es una variable determinante en la elección y frecuencia de algunas de las actividades a las que vinculan su tiempo libre, así como en su mayor o menor orientación hacia un ocio que sea pedagógica y socialmente activo, creativo y formativo. Es el caso de la asistencia a bares o espacios de diversión, que se incrementa con la edad. En sentido contrario, la realización de actividades artísticas, lúdicas, recreativas, etc. como la música, la pintura, el deporte, jugar en el parque o en la calle y caminar o pasear, es más frecuente entre adolescentes más jóvenes. Considerando estas circunstancias, la Pedagogía-Educación del Ocio, dentro y fuera de las instituciones escolares, debe asumir el importante desafío que comporta abrir la vida de las personas a otros futuros, en los que aspirar a la felicidad no se reduzca, simplemente, a estar entretenido. higher the level of their education is, the less time their teens spend in leisure electronic devices. Something similar happens if you look at the percentages of adolescents who are chatting and surfing through different social networks.

Note that, regardless of the differences on $\mathrm{fa}$ mily education, a common pattern is observed in the leisure activities' choice. The employment status of the parents seems crucial in the time devoted to the electronic games, watching television and being with family.

Finally, we would like to point out that there are many evidences suggesting that the age of adolescents is a variable that influence the choice and frequency of some of the activities related to their free time, as well as their higher or lower orientation towards a leisure that is educational and socially active, creative and formative. It is the case of attendance to bars or places of amusement, that increases with age. In contrary, performing artistic, recreational and leisure activities, etc. as playing music, painting, practising sport, playing in the park or on the street and walk, it is more common among younger adolescents. Considering these circumstances, the Leisure Pedagogy-Education, inside and outside the school institutions, should assume a major challenge involved in opening people's lives to other futures, in which aspiring to happiness is not reduced, just to be entertained.

[ 46 ] JOAO PAULO FERREIRA DELGADO, HÉCTOR POSE PORTO Y ÁNGELA LUCÍA DE VALENZUELA BANDÍN SIPS - PEDAGOGIA SOCIAL. REVISTA INTERUNIVERSITARIA [1139-1723 (2015) 25, 25-49] TERCERA ÉPOCA 


\section{REFERENCIAS BIBLIOGRÁFICAS/ BIBLIOGRAPHIC REFERENCES}

Bas, E. (2014). Educar para innovar: La innovación como cultura. Juventud, proactividad, creatividad, participación y visión de futuro compartida. Revista de Estudios de Juventud, 104, 11-30. Retrieved from:

http://www.injuve.es/sites/default/files/2014/31/publicaciones/Documento\%201.\%20Educar\%20para\%20i nnovar.pdf

Blanco, I. (2006). Juventud, ocio nocturno y participación: retos para las políticas públicas locales. Adoz, 30, 79-84.

Capucha, L. (Coord.) (2005). Formulação de Propostas de Conceção Estratégica das Intervenções Operacionais no Domínio da Inclusão Social. Lisboa: Direção Geral de Desenvolvimento Regional e Instituto Superior de Ciências do Trabalho e da Empresa.

Caride, J.A. (2005). Las fronteras de la Pedagogia Social: perspectivas científica e histórica. Barcelona: Gedisa.

Caride, J.A., Lorenzo, J. \& Rodríguez, M. (2012). Educar cotidianamente: el tiempo como escenario pedagógico y social en la adolescencia escolarizada. Pedagogía Social. Revista Interuniversitaria, 20, 19-60. doi: 10.7179/psri_2012.20.1

Cuenca, M. (2004). Pedagogía del Ocio: Modelos y Propuestas. Bilbao: Universidad de Deusto.

Cuenca, M. (2009a). Perspectivas actuales de la pedagogía del ocio y el tiempo libre. In J.C. Otero López (coord.). La Pedagogía del Ocio: Nuevos desafíos. Lugo: Axac. Colección Perspectiva Pedagógica, 4, 9-23.

Cuenca, M. (2009b). Ocio humanista. Dimensiones y manifestaciones actuales del ocio.

Bilbao: Universidad de Deusto.

Cuenca, M. (2011a). El ocio como ámbito de Educación Social. Educación Social Revista de Intervención Socioeducativa, 47, 25-40.

Cuenca, M. (2011b). Valores que dimanan del ocio humanista. In A. Madariaga y J. Cuenca (eds.): Los valores del ocio: cambio, choque e innovación. Bilbao: Universidad de Deusto, 17-47.

Cyrulnik, B. (2002). Los patitos feos. La resiliencia: una infancia infeliz no determina la vida. Barcelona: Gedisa.

Delgado, P. (2006). Os Direitos da criança. Da participação à responsabilidade. Porto: Profedições.

Ferreira, I., Delgado, P. \& Freitas, O. (2012). Cambios en las condiciones de vida de los portugueses en las tres últimas décadas: (re)configuraciones del trabajo y del consumo y (re)invenciones del ocio y de la ciudadanía. In J. Cuenca \& J. Doistua (eds.): Ociogune 2012. El ocio trans-formado(r). Resignificaciones y tendencias del ocio en tiempos de crisis. Bilbao: Universidad de Deusto, 149-164.

Gilligan, R. (2009). Promoting resilience. Supporting children and young people who are in care, adopted or in need. London: BAAF. doi: 10.1111/j.1475-3588.2010.00582_11.x

Jackson, S. \& Sachdev, D. (2001). Better education, better futures. Research, practice and the views of young people in public care. Ilford: Barnardo's.

Lazcano, I. \& Doistua, J. (eds.) (2010). Espacio y experiencia de ocio: consolidación, transformación y virtualidad. Bilbao: Universidad de Deusto.

Melendro, M., Rodríguez, A.E., González, A.L. \& De Juanas, A. (2013). Intervención-acción socioeducativa y nuevas formas de exclusión social en la adolescencia. In Torío, S.; García-Pérez, O., Peña, J.V.\& Fernández García, C.Ma. (coords.): La crisis social y el Estado del Bienestar: Las respuestas de la Pedagogía Social. Oviedo: Universidad de Oviedo, 136-144.

Ministerio de Educación, Cultura e Deporte (2012). Estadísticas de la educación. Enseñanzas no universitarias. Alumnado. Retrieved from http://www.educacion.gob.es/horizontales/estadisticas/no-universitaria/ alumnado/matriculado/series.html

Monteagudo, Ma.J. (2004). Los beneficios del ocio ¿̇qué son y para qué sirven? Adoz, 28, 63-72.

Morán, Ma C., Iglesias, L., Vargas, G. \& Rouco, J. F. (2012). Usos e imágenes del tiempo en el alumnado de 
Educación Secundaria Obligatoria (ESO): entre la escuela, la familia y la comunidad. Pedagogía Social. Revista Interuniversitaria, 20, 61-101. doi: 10.7179/psri_2012.20.2

Ortega, C. \& Bayón, F. (2014). El papel del ocio en la construcción social del joven. Bilbao: Universidad de Deusto.

Stebbins, R.A. (2012). The Idea of Leisure. First Principles. New Jersey: Transaction Publishers.

\section{Notas / Notes}

${ }^{1}$ El artículo que presentamos se vincula a dos proyectos de investigación cofinanciados por el Fondo Europeo de Desarrollo Regional (FEDER, 2007-2013) y los Ministerios de Educación y Ciencia y de Economía y Competitividad (código EDU2012-39080-C07-00 a 07), en el marco del Plan Nacional de I+D+i; de los que es IP el prof. Dr. José Antonio Caride, de la Universidad de Santiago de Compostela: "Tiempos escolares y tiempos de ocio: problemáticas específicas y alternativas pedagógico-sociales en la vida cotidiana del alumnado de Educación Secundaria Obligatoria" (TETOSO), "De los tiempos educativos a los tiempos sociales: la construcción cotidiana de la condición juvenil en una sociedad de redes. Problemáticas especificas y alternativas pedagógico-sociales" (RESORTES).

2 The paper presented is related to two research project co-founded by the European Regional Development Funds (ERDF, 2007-2013) and the Ministries of Education and Science and Economy and Competitiveness (Code EDU2O1239080-C07-00 a 07), in the frame of the National Plan of I+D+i; from which the prof. Dr. José Antonio Caride is IP el prof. Dr. José Antonio Caride, from the Universidad de Santiago de Compostela: "School and leisure times: specific problems and socio-pedagogical alternatives in daily live of the GCSE students" (TETOSO) "From educational to social times: the daily young building of the young condition into a network society. Specific problems and socio-pedagogical alternatives." (RESORTES)

3 From now on: GCSE

\section{CÓMO CITAR ESTE ARTÍCULO / HOW TO CITE THE ARTICLE}

Ferreira Delgado, P., Pose Porto, H. \& De Valenzuela Bandín, A. L. (2015). El ocio cotidiano de los estudiantes de Educación secundaria en España. Pedagogía Social. Revista Interuniversitaria, 25 25-49. DOI:10.7179/PSRI_2015.25.2

Fecha de recepción del artículo / received date: 25.VI.2014

Fecha de revisión del artículo: / reviewed date: 26. VI.2014

Fecha de aceptación final / accepted date: 18.X.2014

\section{DIRECCIÓN DE LOS AUTORES/ AUTHOR'S ADDRESS}

Paulo Delgado Ferreira. Escola Superior de Educação do Instituto Politécnico do Porto, R. Dr. Roberto Frias, n. 602. 4200-465 Porto. Dirección de correo/e-mail: pdelgado@ese.ipp.pt

Héctor Pose Porto. Facultade de Educación. Campus Elviña, s/n. Universidade da Coruña. 15071 A Coruña. Dirección de correo/e-mail: hector.pose@udc.es

Ángela de Valenzuela Bandín. Universidad de Santiago de Compostela. Facultad de Ciencias de la Educación-Campus Vida. Departamento de Ta de la Educación, Ha de la Educación y Pedagogía Social. Grupo de Investigación en Pedagogía Social y Educación Ambiental (SEPA-Interea). Dirección de correo/e-mail: angela.devalenzuela@usc.es

\section{PERFIL ACADÉMICO / ACADEMIC PROFILE}

Paulo Delgado Ferreira. Licenciado en Derecho, maestro en Administración de la Educación y Doctor en Ciencias de la Educación por la Universidad de Santiago de Compostela, con agregación en Ciencias de la Educación en la Universidade de Trás-os-Montes e Alto Douro (UTAD), es profesor adjunto en la Escola Superior de Educação do Instituto Politécnico do Porto. Es miembro integrado en el Centro de Investigação em Estudos da Criança (CIEC), da Universidade do Minho y miembro colaborador del Centro de Investigação e Inovação em Educação (INED) de la Escola Superior de Educação do Instituto Politécnico do Porto (ESEP).

[ 48 ] JOAO PAULO FERREIRA DELGADO, HÉCTOR POSE PORTO Y ÁNGELA LUCÍA DE VALENZUELA BANDÍN SIPS - PEDAGOGIA SOCIAL. REVISTA INTERUNIVERSITARIA [1139-1723 (2015) 25, 25-49] TERCERA ÉPOCA 
Héctor Pose Porto. Es Doctor en Psicopedagogía por la Universidade da Coruña. Ha participado como investigador en diversos estudios sociopedagógicos (Jornada Única en Galicia, Mapa Cultural de Galicia, interea...), ponente en numerosos Congresos, Cursos y Jornadas sobre Animación Sociocultural y Gestión Cultural, así como ha publicado artículos y libros sobre asociacionismo, animación sociocultural, animación teatral, etc. Ejerció como Técnico de Educación y Cultura en el Ayuntamiento de Malpica (1991-2000). Actualmente es Profesor en la Facultad de Educación de la Universidade da Coruña. Pertenece a los grupos de investigación SEPA-interea (UsC) y Política Educativa, Historia e Sociedade (UdC).

Ángela de Valenzuela Bandín. Diplomada y habilitada al Grado en Educación Social por la Universidad de Santiago de Compostela (USC), con Premio Extraordinario de Diplomatura en el año 2010. Cuenta con dos másters universitarios: uno centrado en la intervención y emancipación de la juventud en conflicto social y otro en la investigación en educación, diversidad cultural y desarrollo comunitario. Actualmente es doctoranda y becaria predoctoral (FPI) vinculada a un proyecto de investigación coordinado del Plan Nacional de I+D+i (2012-2015) del Ministerio de Economía y Competitividad. 
